\title{
社会福祉法人恩賜財団済生会支部 大阪府済生会泉尾病院
}

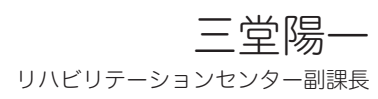

大阪市大正区は“リトル沖縄”と称されるよう に，建物の門や屋根には守神である “シーサー”が 据えられ，沖縄の柔和な雲囲気を感じられる街で す。一方では，市内でも急速に高齢化が進む区の 1 つであり, 地域の特性・実情に応じた地域包括ケ アシステムの構築が課題となっています.

当院は大阪市の南西部に位置する, 泉尾医療福 祉センター内にある 440 床 (一般病床 274 床, HCU 6 床, 回復期リハビリテーション病棟 60 床, 地域包括ケア病棟 60 床, 療養病棟 40 床）の総合 病院です.

泉尾医療福祉センターとは, 特別養護老人ホー ム, 軽費老人ホーム, 障害者支援施設, 在宅介護 部門を有し，当院を中核とした医療，福祉，保健を トータルに提供する総合施設です.

2019 年 3 月現在, 医師 3 名, 理学療法士 44 名, 作業療法士 13 名, 言語聴覚士 9 名が在籍してい ます。認定資格者は, 認定臨床医 2 名, 専門医 · 指導医 1 名, 心臓リハビリテーション指導士 4 名, 3 学会合同呼吸療法認定士 10 名, 呼吸ケア指導士 3 名, 認定理学療法士 1 名, 回復期セラピストマネ ジャー 1 名, 認定訪問療法士 2 名が在籍し, 専門 性に特化した診療にあたっています.

当院の特徵は, 超急性期から回復期・生活期ま で切れ目のない, シームレスなリハビリテーション 診療を行っていることにあります，疾患領域は小 児以外のすべてを網羅し，2018 年 12 月からは心 臓血管外科の新設に伴い, 心血管術後リハビリテー ション治療も開始しました。他職種との連携によ

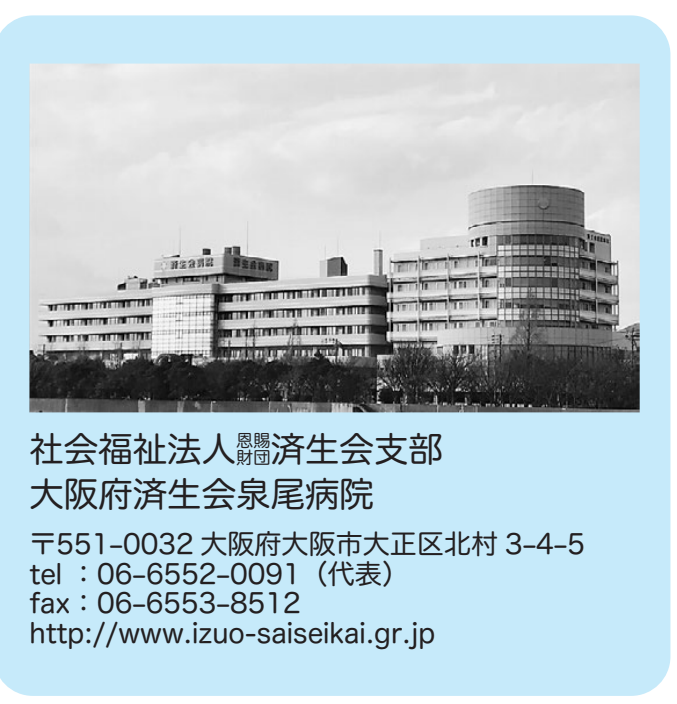

るリスク管理を徹底し，早期からのリハビリテー ション診療の提供を実現しています。また, 呼吸・ 栄養サポートや緩和・裖瘡ケアチームの一員として 役割を担い，活発な意見交換によるチーム医療を 推進しています.

回復期リハビリテーション病棟と地域包括ケア 病棟は, 急性期治療後の後方支援病棟やレスパイ 卜入院の受け入れ病棟として機能しています. 住 環境や介護負担に問題を抱えたご高齢の方が多 く, 在宅復帰に苦慮することもありますが, 家屋評 価や地域連携カンファレンスを通じて, 心身機能 に応じた環境設定や社会資源の活用を行い, 親し い人々の待つ住み慣れた地域での暮らしを続けら れるよう取り組んでいます。

在宅領域である訪問リハビリテーションでは, 経 験豊富な専属セラピストを配置し, 訪問リハビリ 


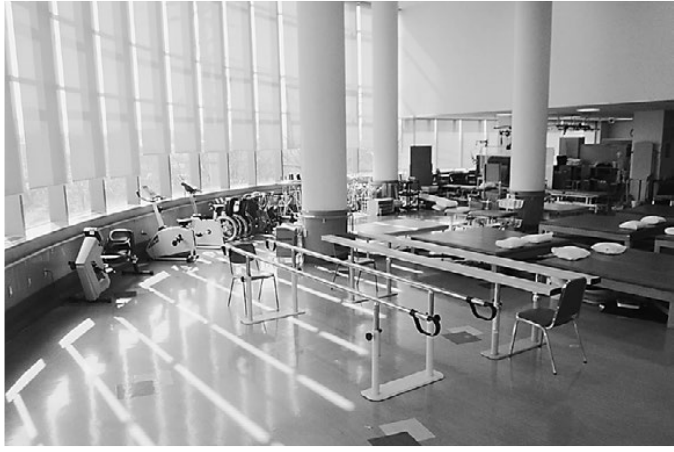

リハビリテーションセンター

テーション対象者と入院中からかかわることで, 在 宅生活へのすみやかな移行を可能とし，住み慣れ た地域での生活が継続できるように支援していま す.また，院外業務として，行政や地域包括支援 センターからの依頼に応じて, 予防事業や地域ケ ア会議へも参画しています。

教育体制は, 先輩セラピストが 3 年目までの新 人セラピストと診療に同行し, 臨床現場での知識・ 技術指導に努めています．毎年，「リハセンター研 究会」を開催し, 研究報告の場を設け, 学会発表へ の足がかりとしています。セラピストが自主的に 課題や目標を見出し，全国学会や研修会で最新の 知見を学び，臨床実践できる体制を整えています。

大阪湾の内港に面した運河や，六甲・金剛生駒 山系の稜線が描く, 素晴らしい景観を楽しむこと

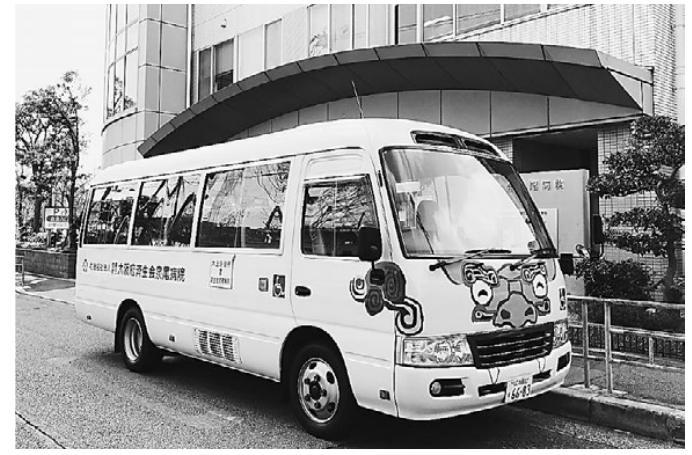

“シーサー”をモチーフにした送迎バス

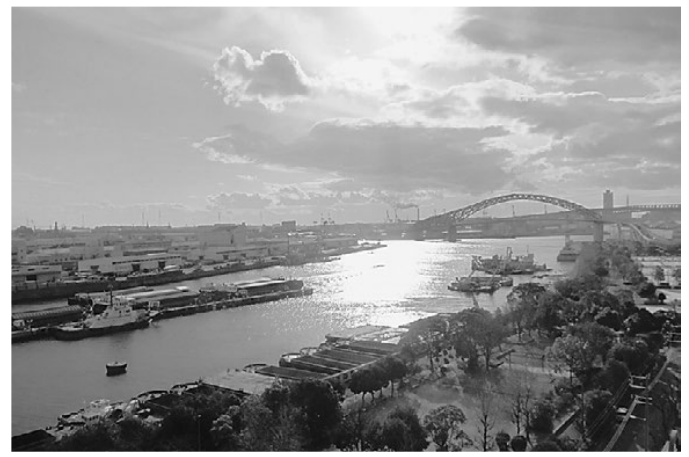

病院屋上から望む大阪湾に面した内港

ができるのも当院の自慢の 1 つです，済生会の理 念である “救療済生”を胸に刻み，信頼いただける 質の高いリハビリテーション診療の提供に尽力い たします。 